\title{
Pengembangan Masyarakat berbasis Aset sebagai Upaya Pemberdayaan Masyarakat melalui Sektor Wisata Kebugaran di Indonesia
}

\author{
Theofillius Baratova Axellino Kristanto ${ }^{1}$, Ayu Aishya Putri ${ }^{2}$
}

\begin{abstract}
Abstrak
Pengembangan wisata kebugaran di Indonesia haruslah menjadi prioritas utama pasca keterpurukan pariwisata ketika pandemi COVID-19 berlangsung. Berbekal pada potensi masa depan yang menggiurkan baik pada ranah global maupun domestik, sektor wisata kebugaran di Indonesia dapat menjadi kekuatan perekonomian negara. Namun, dengan adanya potensi yang gemilang juga diperlukan kondisi masyarakat yang matang guna mengelola potensi yang ada. Tulisan yang ditulis dengan metode kajian literatur secara naratif ini berusaha menganalisis pengembangan masyarakat berbasis aset atau Asset-Based Community Development (ABCD) sebagai pendekatan yang tepat bagi pemberdayaan masyarakat tersebut. Kemudian hasil analisis menunjukkan potensi masa depan wisata kebugaran Indonesia, langkah-langkah pengembangan ABCD, hingga tantangan pemberdayaan masyarakat yang ada. Tulisan ini kemudian menyimpulkan bahwa ABCD dinilai sebagai pendekatan yang tepat bagi pemberdayaan masyarakat guna pengembangan wisata kebugaran di Indonesia.
\end{abstract}

Kata kunci: Pengembangan Masyarakat berbasis Aset, Pemberdayaan Masyarakat, Wisata Kebugaran.

\begin{abstract}
The development of wisata kebugaran in Indonesia must be the first priority after the loss of the tourism sector during the COVID-19 pandemic. With the future opportunity both in the global and domestic spheres, the health tourism sector in Indonesia can become the strength of the country's economy. An advanced community condition is also needed to manage the existing opportunity. This paper, written using narrative literature review, attempts to analyze AssetBased Community Development (ABCD) as the right approach for community empowerment. Then the results of the analysis show the future opportunity of Indonesian wellness tourism the steps for developing $A B C D$, and the challenges of community empowerment that exist. This paper then concludes that ABCD is considered the right approach for community empowerment for the development of health tourism in Indonesia.
\end{abstract}

Keywords: Asset-Based Community Development, Community Development, Wellness Tourism.

\section{Pendahuluan}

Pariwisata menjadi salah satu sektor yang paling terpukul selama pandemi COVID-19. Pembatasan dan pelarangan perjalanan menjadikan sektor pariwisata mengalami banyak tantangan (Motevalli-Taher \& Paydar, 2021). Hal tersebut berakibat pada kerugian yang cukup besar pada devisa negara, tak terkecuali Indonesia yang mengandalkan sektor pariwisata sebagai salah satu sumber devisa negara. Terlebih sebelum pandemi pembangunan Indonesia menekankan salah satunya pada pengoptimalan pariwisata, dengan target utama wisatawan mancanegara sebagai pemasok devisa dari sektor pariwisata.
Seperti yang dicatatkan oleh data Badan Pusat Statistik (2021) bahwa pada tahun 2020, terjadi penurunan wisatawan Indonesia baik domestik maupun mancanegara hingga lebih dari $75 \%$ yang otomatis membawa kerugian yang signifikan bagi pendapatan negara dari sektor pariwisata.

Dengan berbagai kendala dan tantangan yang dihadapi sektor pariwisata Indonesia selama pandemi, pemerintah dan berbagai pihak terkait terpaksa memutar otak menyusun kembali target pariwisata yang sebelumnya sudah terencana. Hal ini menjadi tanggung jawab bersama stakeholder pariwisata dalam bersikap tanggap, fleksibel, dan terbuka atas segala

\footnotetext{
${ }^{1}$ Departemen Sosiologi, Universitas Gadjah Mada (email korespondensi: theofillius@mail.ugm.ac.id)

${ }^{2}$ Departemen Sosiologi, Universitas Gadjah Mada (email: ayu.aishya.putri@mail.ugm.ac.id)
} 
Theofillius Baratova Axellino Kristanto, Ayu Aishya Putri - Pengembangan Masyarakat Berbasis Aset sebagai Upaya Pemberdayaan Masyarakat melalui Sektor Wisata Kebugaran di Indonesia

perubahan yang ada (Sigala, 2018). Sebagai respons dari keadaan tersebut, Indonesia sebenarnya memiliki cukup potensi untuk memulihkan sektor pariwisata, terutama pariwisata dalam negeri atau domestik. Berbagai pembatasan yang dilakukan menggiring masyarakat untuk berwisata dalam kancah lokal. Peluang tersebut menjadi hal yang dapat dimanfaatkan dengan melihat perubahan pola hidup masyarakat.

Tren hidup sehat yang muncul di tengahtengah masyarakat Indonesia karena pandemi COVID-19, menjadi peluang tersendiri untuk pengembangan wisata berbasis kesehatan atau yang disebut dengan wisata kebugaran (Agustina \& Yudhistira 2021; Andreu et al, 2021). Sementara sektor pariwisata mengalami keterpurukan di tengah situasi pandemi COVID-19, perjalanan wisata kebugaran telah mengalami peningkatan terlebih dahulu pada tahun-tahun sebelumnya. Peningkatan yang signifikan disebutkan dengan pertumbuhan global sebesar 74\% dalam rentang tahun 2010 hingga 2013. Tentunya hal ini menjadi potensi yang luar biasa untuk mendongkrak kembali sektor pariwisata Indonesia.

Dilansir dari Wellness Travel Report pada tahun 2013, pemasukan pariwisata global dapat mencapai angka USD 3,4 triliun, dengan sektor wisata kebugaran menyumbangkan pemasukan senilai USD 494 milyar. Pada tahun 2017 diperkirakan oleh Global Wellness Institute, perjalanan dengan motivasi kebugaran mencapai 830 juta kunjungan dan total pembelanjaan sekitar USD 639,4 milyar. Diproyeksikan juga pertumbuhan perjalanan wisata kebugaran dapat mencapai $9 \%$ per tahun, lebih tinggi dibandingkan pertumbuhan pariwisata secara umum. Hal ini menggambarkan bahwa perjalanan wisata dengan motivasi kesehatan dan kebugaran telah menjadi suatu tren bagi masyarakat global pada umumnya.

Pengembangan wisata kebugaran lebih lanjut dapat dilakukan dengan memanfaatkan potensipotensi yang ada di Indonesia. Kondisi geografis, bentang alam, hingga adat dan kebudayaan yang kaya dapat menjadi kekuatan utama untuk membangun sektor wisata kebugaran secara optimal di kawasan Indonesia. Fokus wisata kebugaran pada pola menjaga kesehatan dengan cara tradisional yang salah satunya adalah obatobatan herbal selaras dengan potensi Indonesia sebagai penghasil utama dari obat-obatan herbal tersebut (Andreu et al, 2021; Meera \& Vinodan 2019; Meikassandra et al, 2020; Utama \& Nyandra 2021). Selain itu, bentang alam pedesaan dengan segala keindahannya dapat digunakan sebagai sarana relaksasi wisatawan.

Perlu adanya penguatan kapasitas masyarakat melalui pemberdayaan guna meningkatkan kapabilitas wisata kebugaran di Indonesia. Keselarasan antara potensi dan juga kapasitas masyarakat dalam mengembangkan potensi tersebut sangat diperlukan bagi wisata kebugaran di Indonesia. Hal ini dapat dilakukan melalui pendekatan pengembangan masyarakat berbasis aset atau Asset-Based Community Development (ABCD) yang dikemukakan oleh John McKnight dan Jody Kretzmann. Pendekatan ini bertolak pada kekuatan dan potensi yang melekat pada masyarakat itu sendiri. Hal ini berbeda dibandingkan dengan strategi pemberdayaan masyarakat lain yang cenderung mencari hulu dari permasalahan yang ada. ABCD melihat potensi sebagai sumber daya pemberdayaan dalam masyarakat yang paling efektif. Melalui $\mathrm{ABCD}$, masyarakat mengembangkan dirinya sebagai produsen dari kesejahteraannya sendiri, dibandingkan hanya menerima layanan dari pihak luar semata (McKnight, 2017).

Potensi-potensi yang terdapat dalam pedesaan-pedesaan di Indonesia secara langsung maupun tidak langsung melekat dengan struktur masyarakat yang ada. Selain itu, pengembangan pariwisata kesehatan dapat ditemukan di hampir seluruh wilayah Indonesia. Sehingga potensi tersebut juga dapat menjadi sumber pemberdayaan masyarakat lokal. Melalui skema $A B C D$ inilah kemudian masyarakat lokal pedesaan Indonesia diharapkan mampu mengembangkan potensi yang ada guna mendorong upaya pengembangan wisata kebugaran di Indonesia.

\section{Kerangka Teori}

Wisata kebugaran dapat dipahami sebagai konsep bisnis pariwisata yang merupakan bagian dari health tourism dan sederajat dengan bisnis pariwisata lainnya (Mueller \& Kaufmann , 2007). Wisata kebugaran identik dengan upaya preventif terhadap terjadinya sakit penyakit dalam tubuh manusia. Jenis wisata ini mengutamakan terjadinya harmoni atau keseimbangan antara jiwa dan tubuh seseorang terlebih mengenai bagaimana harmoni tersebut 
dapat menjamin seseorang agar tetap sehat dan bugar. Karena itu wisata kebugaran berkaitan erat dengan keputusan seseorang untuk mengarahkan diri ke dalam gaya hidup sehat melalui aktivitas pariwisata. Artinya seseorang tersebut bertanggung jawab atas kualitas hidup dan membentuk kesadaran untuk memulai gaya hidup sehat (De La Barre, 2005).

Pariwisata wisata kebugaran telah menjadi tren global yang cukup signifikan dalam perkembangannya. Pada dasarnya pelaku perjalanan ini memiliki tujuan untuk meningkatkan kebugaran fisik melalui berbagai macam latihan fisik dan terapi, kontrol diet dan pelayanan medis yang relevan dengan pemeliharaan kesehatan. Sejak kemunculannya, jenis wisata ini cukup digemari oleh masyarakat secara umum, terlebih bagi masyarakat perkotaan. Kejenuhan dan keletihan akan hiruk pikuk industri membuka peluang yang cukup tinggi bagi para pekerja tersebut untuk menemukan pelayanan yang tepat dalam menjaga pola hidup sehat.

Melihat adanya tren yang positif dan peluang masa depan perkembangan bisnis wisata kebugaran, Asia telah menjadi primadona bagi para pelaku perjalanan wisata kebugaran dalam memenuhi kebutuhannya. Menurut Global Wellness Economy Monitor, sejak tahun 2013 negara-negara di Asia merupakan negara yang paling banyak menerima wellness trip dan wisata kebugaran di dunia. Potensi pasar Asia mengalami lonjakan drastis yaitu 33\% terhitung dari tahun 2015 hingga 2017. Bahkan pertumbuhan pasar sektor pariwisata ini pada tahun 2017 hingga 2022 diproyeksikan dapat mencapai angka pemasukan senilai USD 252 milyar. Beberapa negara juga ditetapkan sebagai pasar potensial, antara lain adalah Tiongkok, India, Malaysia, Filipina, Vietnam, dan Indonesia. Dengan adanya hal tersebut tentunya hal ini dapat menjadi potensi bahan bakar penggerak perekonomian di kawasan Asia.

Kepopuleran Asia sebagai destinasi wisata kebugaran tidak dapat terlepas dari potensi alamiah di kawasan Asia itu sendiri. Negaranegara di Asia mampu memenuhi kebutuhan para wisatawan yang ada seperti tersedianya layanan relaksasi tubuh dan pikiran, berbagai macam bentuk terapi kesehatan dan kebugaran, hingga perawatan kecantikan. Wisata kebugaran dapat diasosiasikan dengan timbulnya perasaan yang lebih baik setelah melakukan perjalanan wisata, penurunan berat badan, pengelolaan stres, dan lain sebagainya (Chen et al, 2013; Steiner \& Reisinger 2006). Ketersediaan potensi alam yang cukup baik di kawasan Asia telah menjadi faktor penarik bagi para wisatawan global untuk berkunjung (Utama \& Nyandra, 2021). Pertama adalah tersedianya berbagai macam bentuk tradisi dan teknik penyembuhan (yoga, akupuntur, ayurveda, dan meditasi). Kedua, negara-negara di Asia sangat kental dengan pemanfaatan rempah-rempah yang kaya untuk berbagai macam ramuan kecantikan, pengobatan, dan bumbu masakan. Lalu yang ketiga adalah adanya agama dan filsafat guna mendukung penyegaran mental dan pikiran dari para wisatawan yang ada.

Potensi wisata kebugaran di Asia tidak dapat dipungkiri lagi telah menjadi suatu keuntungan besar bagi sektor ekonomi dan pariwisata. Terdapat beberapa alasan mengapa wisata kebugaran dapat menjadi salah satu kekuatan perekonomian suatu negara, terutama bagi negara-negara di kawasan Asia. Setidaknya terdapat tiga potensi utama dalam perkembangan wisata kebugaran di masa depan.

Pertama, wisata kebugaran telah menjadi tren masyarakat dunia untuk mewujudkan kebugaran dan kesehatan (Kurniawan, 2018). Saat ini, memiliki tubuh yang terlihat sehat merupakan kebanggaan bagi sebagian besar orang di dunia. Hal ini diidentikkan dengan tubuh yang langsing, cerah, awet muda, dan lain sebagainya yang tentunya membuat masyarakat berlomba-lomba untuk memilikinya. Melihat hal tersebut, kemudian akses terhadap wisata kebugaran menjadi suatu bentuk yang cukup prestisius dalam masyarakat. Sebab dengan melakukan jenis perjalanan wisata ini, kondisi tubuh yang diinginkan dapat terpenuhi.

Kedua, produk-produk kebutuhan terhadap wisata kebugaran akan terus berkembang tergantung pada faktor sosial dan kepekaan lingkungan (Mueller \& Kaufmann, 2007). Apabila ditelisik secara garis historisnya, wisata kebugaran berawal dari kebutuhan para pekerja industri yang lelah akibat rutinitas produksi. Maka dari itu, guna melepas kepenatan yang ada, diciptakanlah pemandian air panas untuk meredakan berbagai macam bentuk stres dan pengaruh kegiatan industri yang membelenggu baik aspek fisik maupun psikis individu (Ross, 2001). Kebiasaan ini kemudian menjamur pada masyarakat industri, sehingga setelah 
Theofillius Baratova Axellino Kristanto, Ayu Aishya Putri - Pengembangan Masyarakat Berbasis Aset sebagai Upaya Pemberdayaan Masyarakat melalui Sektor Wisata Kebugaran di Indonesia

cukup banyak digemari oleh masyarakat, kebutuhan akan praktik ini semakin diminati oleh banyak orang. Harmoni antara tubuh, jiwa, dan pikiran menjadi salah satu kebutuhan bagi para pekerja industri, terutama bagi masyarakat perkotaan. Sehingga daripada itu, demi memenuhi kebutuhan peminat akibat perkembangan industri dan segala aktivitasnya, praktik kebugaran dan kesehatan juga semakin bervariasi. Praktik ini bergerak semakin lebar dan luas hingga melahirkan berbagai inovasi terbarukan seperti spa dan berbagai produk olahan herbal.

Ketiga, perkembangan wisata kebugaran didukung oleh kemunculan baby boomers dalam kebutuhannya melakukan perjalanan kesehatan (Kurniawan, 2018). Generasi baby boomers adalah seseorang yang terlahir di antara tahun 1946 hingga 1964. Kemunculan generasi ini mendorong kebutuhan akan terapi alternatif non medis guna mempertahankan kondisi tubuh yang sehat. Para baby boomers sangat rentan terkena berbagai macam penyakit di usianya yang sudah tergolong tua. Ditambah lagi dengan aktivitas pekerjaan yang membelenggu mereka selama bertahun-tahun. Generasi ini memerlukan pola hidup sehat untuk menghindarkan mereka dari sakit penyakit yang ada. Berbagai macam bentuk layanan wisata kebugaran dapat memenuhi kebutuhan dan preferensi kesehatan dari para baby boomers tersebut. Misalnya pada upaya preventif terhadap penyakit seperti jantung, stroke, hingga diabetes. Hal tersebut dapat dipenuhi melalui perawatan kebugaran serta produk-produk herbal. Artinya, dalam hal ini produk-produk dari wisata kebugaran masih menjadi pilihan utama. Dengan demikian mengakibatkan perjalanan wisata kesehatan dan kebugaran cukup banyak digandrungi oleh masyarakat yang berasal dari generasi baby boomers.

Beranjak dari potensi yang ada dalam pengembangan wisata kebugaran di Indonesia. Diperlukan pemberdayaan masyarakat yang kuat guna menyokong pembangunan sektor wisata kebugaran tersebut. Maka dari itu ABCD dianggap sebagai metode yang paling tepat bagi perkembangannya. ABCD merupakan pendekatan pada pemberdayaan masyarakat yang berangkat dari potensi yang dimiliki oleh masyarakat. Pendekatan ini diciptakan dan dikembangkan oleh John McKnight dan Jody Kretzmann (McKnight, 2017). Dengan melihat potensi yang ada di masyarakat sebagai dasar melakukan pembayaran masyarakat, ABCD menaruh nilai lebih pada adanya kapasitas, pengetahuan, kemampuan, dan konektivitas di dalam suatu masyarakat sebagai hal yang paling berharga.

Berbeda dengan proses pemberdayaan yang lainnya yang menitikberatkan pada tersedianya program untuk mengentaskan permasalahan dalam komunitas, ABCD melihat masyarakat lokal sebagai jawaban dari permasalahan yang ada. Proses ABCD dalam masyarakat meliputi inventarisasi dan pemetaan potensi di masyarakat hingga membangun konektivitas antara anggota komunitas dan agensi guna menuju perubahan yang diharapkan (Foot \& Hopkins, 2009). Dengan menempatkan pendekatan ABCD sebagai upaya pemberdayaan masyarakat dalam pengembangan wisata kebugaran adalah langkah yang tepat. Hal ini disebabkan karena melihat potensi wisata kebugaran yang ada di Indonesia yang tentunya juga melekat pada masyarakat lokal itu sendiri.

\section{Metode Penelitian}

Penelitian ini dilakukan dengan melakukan kajian literatur secara naratif. Kajian literatur naratif merupakan pendekatan yang mengedepankan diskusi dengan mengacu pada literatur yang telah dipilih (Cronin et al, 2008). Metode ini mengedepankan subjektivitas peneliti dalam melakukan pemilihan dan interpretasi literatur (Snyder, 2019). Data yang diperoleh didasarkan pada tinjauan literatur yang dilakukan terhadap berbagai macam sumber baik itu jurnal, media massa, buku, hingga laporan yang dikeluarkan oleh lembagalembaga yang dianggap relevan dengan isu ini. Tinjauan literatur dilakukan dengan memilih dan menyoroti kata kunci wisata kebugaran serta pengembangan masyarakat berbasis ABCD. Peneliti kemudian menemukan sejumlah literatur yang berasal dari sumber baik nasional Indonesia maupun internasional yang dianggap representatif terhadap penelitian ini.

Melalui serangkaian proses seleksi menyeluruh terhadap tinjauan literatur yang telah dilakukan, sajian data dan juga temuan termuat secara sistematis dalam tulisan ini. Peneliti mengambil contoh kasus dari penerapan ABCD dalam beberapa kawasan wisata perkebunan teh di Indonesia yang dapat dijadikan model panduan pengembangan. 
Maka dari itu beranjak dari permasalahan yang ada dan juga hasil studi literatur yang telah dilakukan, peneliti kemudian merumuskan permasalahan penelitian yaitu: Bagaimana ABCD dapat dijadikan sebagai model pendekatan pemberdayaan masyarakat yang tepat dalam upaya pengembangan wisata kebugaran di Indonesia? Serta bagaimana wisata kebugaran dapat menjadi potensi kebangkitan pariwisata Indonesia pasca pandemi COVID-19?

\section{Hasil}

Pertama, sektor individu menjadi langkah awal bagaimana ABCD dapat terwujud. Dalam proses pemberdayaan masyarakat, mengenali setiap individu dalam kelompok secara mendasar dan mendetail adalah langkah terbaik yang harus ditempuh. Karena hanya dengan memahami individu-individu yang ada, proses inventarisasi dan pemetaan terhadap potensi yang dimiliki individu dalam mengembangkan masyarakat tersebut akan menjadi optimal (McKnight, 2017). Memetakan potensi individu dalam mengembangkan sektor wisata kebugaran di Indonesia menjadi suatu hal yang penting. Pada dasarnya dengan potensi wisata kebugaran Indonesia yang cukup baik tersebut apabila tidak diimbangi dengan sumber daya manusia yang tepat sasaran hanya akan menimbulkan aksi yang sia-sia.

Fokus utamanya bukan berada pada proses homogenitas individu dalam membangun sumber daya yang ada melalui edukasi. Namun lebih dari itu, heterogenitas dalam kelompok menjadi hal yang sangat penting untuk menempatkan individu pada posisi yang tepat. Masalah utamanya terletak pada proses transformasi yang bersifat ekstrem. Terutama pada masyarakat pedesaan yang terkenal dengan tindakan kolektifnya (Nasdian, 2015). Proses pertama ini akan menggeser individu dari kegiatan kolektif menjadi organisasi terstruktur yang berdasarkan pada karakteristik masing-masing individu dalam memenuhi perannya ketika memaksimalkan potensi wisata kebugaran di daerah tersebut.

Sebagai contohnya, Rahmat (2010) dalam pengembangan masyarakat yang terdapat di kawasan perkebunan teh Kemuning, Karanganyar, Jawa Tengah sejak semula telah terjadi pembagian kerja yang terstruktur dan terorganisir antara satu individu dengan individu yang lain. Bahkan adanya pembagian kerja ini telah diinisiasi sejak penjajahan Belanda. Sekalipun pada mulanya ditujukan untuk produksi komoditas teh semata, namun dari proses pembagian kerja ini akhirnya mampu membawa masyarakat setempat dan kawasan yang ada menjadi salah satu tempat relaksasi pilihan bagi banyak orang untuk mendapatkan kembali kebugaran mereka.

Pembagian kerja ini kemudian semakin diperkuat dengan kemunculan sekolahsekolah yang menghadirkan edukasi terhadap masyarakat lokal berbasis dengan pemenuhan kebutuhan produksi komoditas teh yang ada. Masyarakat pun juga kemudian terbagi menjadi banyak sektor sesuai dengan keahlian yang dimiliki. Terdapat masyarakat yang melakukan proses penanaman hingga panen komoditas teh, juga terdapat masyarakat yang mengurus masalah transportasi, bahkan saat ini juga terdapat kelompok masyarakat yang mengurus sektor pariwisata yang ada. Struktur organisasi juga terbentuk sejak tahun 1946 dengan keberadaan direksi hingga mandor-mandor dalam proses produksi komoditas teh.

Pemberdayaan masyarakat ini bukanlah bertujuan untuk mengubah gaya hidup dan kebudayaan masyarakat. Melainkan program ini justru menguatkan kebudayaan yang ada guna mendukung pemberdayaan masyarakat terhadap wisata kebugaran di Indonesia. Maka dari itu, individu perlu dikelompokkan ke dalam grup-grup yang berdasarkan atas kemampuan atau ketertarikan yang sama. Dengan demikian, akan terbentuk kelompokkelompok yang memiliki peran berbeda namun dapat disinergikan dengan kebutuhan fungsional di dalam proses pemberdayaan masyarakat tersebut (McKnight, 2017). Langkah ini disebut dengan komunitas.

Misalnya pada masyarakat desa industri jamu, memahami individu-individu yang ada secara mendasar merupakan hal yang penting, untuk kemudian menempatkan mereka pada kelompok-kelompok berdasarkan kemampuan atau ketertarikan yang sama. Ada individu yang memahami betul cara bercocok tanam, pemilik lahan, peramu, hingga melakukan perdagangan. Proses pengumpulan informasi ini dapat dilakukan dengan cara Focus Group Discussion guna menyerap informasi sebanyakbanyaknya mengenai potensi individu dan kelompok yang ada. Maka dari itu, fasilitator harus terjun secara partisipatif di lapangan 
Theofillius Baratova Axellino Kristanto, Ayu Aishya Putri - Pengembangan Masyarakat Berbasis Aset sebagai Upaya Pemberdayaan Masyarakat melalui Sektor Wisata Kebugaran di Indonesia

dan berinteraksi langsung dengan masyarakat yang ada agar memahami betul bagaimana kondisi dan dinamika di dalam kelompok yang diberdayakan.

Dalam kasus yang sama, perkebunan teh Kemuning seperti yang dijelaskan di atas kemudian dari proses pertama yang menentukan spesialisasi dari masing-masing individu, kemudian menempatkan individu-individu tersebut dalam posisi-posisi yang tepat sesuai dengan kapasitas dan kapabilitas mereka. Dari penempatan tersebut kemudian dapat berjalan suatu pergerakan sistem yang dinamis guna mendorong roda perubahan. Hingga akhirnya struktur organisasi yang ada akan menciptakan suatu sinergi dan harmoni yang positif dalam mendukung pengembangan wisata kebugaran yang ada.

Sejalan juga dengan perkebunan teh, terdapat pula di daerah lain yakni Wonosari, Malang, Jawa Timur juga terdapat suatu pengembangan masyarakat perkebunan teh berbasis wisata kebugaran. Di tempat ini pengembangan wisata kebugaran diprioritaskan dalam dua kegiatan utama yakni kunjungan dan menginap. Namun yang perlu disoroti adalah kegiatan masyarakat setempat yang terbagi secara apik melalui skema komunitas yang berbeda. Dalam kasus kebun teh Wonosari ini, masyarakat dikelompokkan menjadi beberapa bagian. Ada masyarakat yang tergabung dalam kelompok tani, juga terdapat kelompok masyarakat yang tergabung dalam kelompok penambangan batu. Kelompok tani tidak sebatas pada pertanian teh saja, melainkan juga komoditas lain yang terdapat dalam kawasan tersebut. Juga terdapat kelompok penambangan batu yang bertugas untuk mengumpulkan material guna menunjang sarana pariwisata di kawasan tersebut (Baskara, 2005).

Konsep alam dan wisata pedesaan yang ada dalam perkebunan teh tersebut menjadi suatu daya tarik yang cukup menjual bagi para wisatawan yang ada. Konsep tersebut juga ditambah dengan kehadiran perusahaan perhotelan dan rekreasi yang kemudian menciptakan suatu sinergitas untuk membangun daerah wisata kebugaran terpadu yang ada di daerah Wonosari, Malang.

Kemudian, institusi adalah langkah ketiga. Institusi cukup mirip dengan komunitas, namun institusi bergerak dengan suatu yang diperjuangkan, atau dengan kata lain institusi berjalan atas dasar upah. Apabila komunitas bergerak atas dasar inisiatif individu, maka institusi bergerak dengan perintah yang lahir dari pemangku jabatan secara normatif (McKnight, 2017). Keberadaan institusi ini cukup penting dalam pengelolaan wisata kebugaran. Karena kelak peran institusi yang akan memberlakukan aturan-aturan teknis yang terdiri atas norma dan nilai yang kemudian disepakati oleh anggota masyarakat secara bersama. Dalam hal ini dapat berbentuk prosedur teknis, peraturan pemerintah, hingga berbagai macam regulasi lainnya yang diperlukan. Selain itu, institusi juga penting karena institusi dapat menjamin suatu kumpulan individu agar dapat menjalankan perannya masing-masing. Misalkan pemangku jabatan struktural seperti RT dan RW atau perangkat desa lainnya. Selain itu juga institusi pendidikan dan juga PKK yang bergerak untuk menghasilkan suatu kesepakatan bersama dalam proses pemberdayaan terhadap masyarakat mengenai potensi wisata kebugaran di Indonesia.

Dalam konsep perkebunan teh yang telah dijelaskan di atas, kehadiran perusahaanperusahaan pengelola dan juga struktur organisasi yang matang telah membawa kontrol sosial yang kuat bagi para kelompok masyarakat yang ada. Baik dari kelompok masyarakat yang bekerja sebagai tani, maupun yang mengambil peran sebagai buruh produksi komoditas, hingga kelompok masyarakat yang mengambil peran dalam pengelolaan jasa pariwisata, adanya institusi ini cukup membantu untuk mengelola keberagaman masyarakat tersebut. Sekalipun institusi yang dimaksudkan adalah dominasi dari pihak swasta, namun keberadaan swasta ini sangat berpengaruh pada pengembangan masyarakat yang ada. Keberadaan swasta juga cukup berpengaruh pada aspek selanjutnya, karena dengan adanya swasta aspek yang ada dapat terpenuhi dengan baik.

Keempat adalah aspek fisik. Aspek fisik ini segala sesuatu yang berkenaan untuk menjalankan proses pemberdayaan masyarakat yang ada (McKnight, 2017). Aspek fisik yang cukup menonjol dan sangat diperlukan guna upaya pemberdayaan masyarakat adalah ketersediaan modal. Baik itu modal sosial, modal manusia, hingga modal fisik sangat diperlukan dalam hal ini. Modal sosial dan modal manusia dapat diperoleh melalui keberadaan masyarakat itu sendiri. Modal sosial merupakan buah 
interaksi dalam masyarakat yang ada. Sehingga ketersediaan modal ini bersifat tidak terbatas dan dapat digunakan kapan saja.

Berbeda dengan modal sosial, modal manusia tidak selalu tersedia dalam suatu masyarakat. Pembagian kerja menjadi penentu tentang bagaimana modal manusia dapat memenuhi peran yang dibutuhkan untuk mengembangkan masyarakat melalui pembagian kerja (Nasdian, 2015). Karakteristik individu dalam masyarakat yang telah diidentifikasi dan dikelompokkan belum tentu mencukupi kebutuhan pemenuhan peran. Maka dari itu perlu menambahkan atau mengembangkan sumber modal manusia di masyarakat tersebut guna memenuhi kebutuhan yang ada. Pendidikan formal dapat menjadi suatu opsi, namun pada dasarnya yang sangat diperlukan adalah keahlian. Maka dari itu dibandingkan dengan menyediakan bentuk pendidikan formal dalam masyarakat, akan jauh lebih efektif untuk menyediakan edukasi terhadap kebutuhan akan kemampuan yang diperlukan.

Selanjutnya modal yang cukup penting adalah modal fisik. Hal ini dapat berupa pendanaan. Dalam hal ini baik perkebunan teh Kemuning dan Wonosari memiliki pendanaan yang juga disumbangkan oleh pihak swasta. Meskipun tidak sepenuhnya pendanaan berasal dari swasta, namun dengan adanya pendanaan ini kemudian roda produksi barang dan jasa yang ada di kawasan wisata kebugaran ini dapat berjalan dengan semestinya. Oleh karena ini hingga saat ini baik Kemuning yang terkenal dengan bisnis teh dan restoran khas alam serta Wonosari yang terkenal dengan penginapan dan kesejukan udara tersebut terdapat pihak swasta yang berperan untuk mendanai pengembangan kawasan yang ada serta menjadi kontrol sosial bagi para pekerja dan kelompok masyarakat agar tetap menjalankan fungsi dan peranannya sesuai dengan yang dibutuhkan.

Langkah kelima yakni komunikasi atau jaringan. Satu persatu aspek ABCD harus saling terhubung satu dengan yang lain (McKnight, 2017). Hal ini tentunya akan berdampak positif pada proses pengembangan yang ada. Masyarakat dapat memahami potensi dirinya dengan maksimal dan mampu memenuhi kebutuhan pengembangan dengan maksimal juga melalui dukungan oleh pemerintah maupun swasta. Namun dalam hal ini, pemerintah yang berwenang seharusnya berada pada level terdekat dengan daerah pengembangan yakni pemerintah lokal atau daerah. Apabila mengandalkan pemerintah pusat, maka akan terjadi pemborosan yang berlebih-lebihan baik itu waktu maupun pendanaan. Sektor desentralisasi harus dikembangkan sedemikian rupa. Karena tingkat keberhasilan program pemberdayaan ini ditentukan dari bagaimana masyarakat mengenali potensi mereka dari dalam ke luar.

\section{Diskusi}

Pemberdayaan masyarakat menjadi kunci penting dalam mengembangkan wisata kebugaran di Indonesia. Hal tersebut harus dilakukan melalui komunitas-komunitas masyarakatlokalyangselamaini seringdipandang sebagai tenaga kasar dalam mengurangi biaya pembangunan. Masyarakat berasosiasi dengan sumber daya manusia, namun alokasi sumber daya manusia tersebut hanya diberdayakan sebatas pada pekerja pembangunan semata. Hal ini membuat masyarakat memiliki kesan keterbatasan pada implementasi atau penerapan program pemerintah saja. Selebihnya, kesadaran masyarakat seolah-olah dibungkam sehingga sangat kecil sekali kemungkinan adanya pengambilan keputusan dari masyarakat itu sendiri. Juga masyarakat yang ada kemudian menjadi tidak terlalu kreatif karena hanya menggantungkan dorongan perubahan dari luar. Tidak ada pengembangan pemberdayaan yang mendorong masyarakat bergerak dari dalam. Padahal, masyarakat memiliki potensi untuk berkontribusi lebih terhadap pembangunan negara secara partisipatif, bukan hanya pasif (Nasdian, 2015).

Potensi dalam masyarakat pedesaan di atas dapat disebut sebagai aset. Kemudian permasalahan yang ada, harus bertemu dengan aset tersebut untuk mewujudkan suatu pemberdayaan masyarakat. Pendekatan ini sering kali disebut dengan pengembangan masyarakat berbasis aset, yakni memaksimalkan, menciptakan sinergitas, dan mengelola aset yang ada guna proses pemberdayaan masyarakat (McKnight, 2017). Perlu dipahami bahwa aset tersebut melingkupi setidaknya lima komponen utama dalam masyarakat. Komponen-komponen tersebut harus dapat bertemu dan bekerja sama mendukung satu dengan yang lain agar iklim pemberdayaan masyarakat dapat terbentuk secara maksimal. 
Theofillius Baratova Axellino Kristanto, Ayu Aishya Putri - Pengembangan Masyarakat Berbasis Aset sebagai Upaya Pemberdayaan Masyarakat melalui Sektor Wisata Kebugaran di Indonesia

Memahami potensi dan kekuatan dari masyarakat lokal merupakan langkah yang tepat dalam proses pemberdayaan masyarakat. Individu atau bahkan kelompok dalam masyarakat akan merasa dibebaskan untuk mengembangkan dirinya melalui sumber daya yang dimiliki. Paul (1987) mengatakan proses partisipasi secara langsung oleh masyarakat akan memicu pertumbuhan daya kreativitas yang digerakkan oleh potensi keuntungan. Hal ini lebih efektif dibandingkan masyarakat hanya sebatas menerima pembagian dari keuntungan proyek yang membuat masyarakat cenderung pasif daripada aktif. Pendekatan ini akan jauh lebih baik untuk diterapkan ketimbang memikirkan apa yang salah dalam suatu masyarakat. Kunci pemberdayaannya adalah dengan memahami potensi yang ada, kemudian memaksimalkan potensi tersebut agar dapat menjadi sumber daya pemberdayaan.

Memahami permasalahan sosial di dalam masyarakat bukanlah suatu hal yang salah. Namun dengan menempatkan individu atau bahkan kelompok untuk bertindak mengatasi sebagaimana masalah tersebut dipahami, rasanya hanya akan menempatkan kelompok menjadi didominasi oleh serangkaian aturan teknis dan tekstual. Sama halnya seperti masyarakat cenderung bertindak secara pasif. Perumusan masalah hingga upaya penyelesaiannya umumnya berasal dari luar kelompok, sebab penekanannya adalah pada bagaimana masyarakat dapat mengentaskan diri dari permasalahannya, bukan pada proses pengoptimalan potensi yang ada. Partisipasi masyarakat berarti masyarakat turut serta mulai dari proses pembuatan keputusan hingga menikmati hasil (Cohen \& Uphoff, 1980).

Secara sederhana, pemberdayaan mengacu kepada kemampuan masyarakat untuk mendapatkan dan memanfaatkan akses ke dan kontrol atas sumber daya yang penting (Nasdian, 2015). Potensi kekayaan alam Indonesia cukup kuat untuk mendorong pengembangan wisata kebugaran itu sendiri. Kemudian karakteristik masyarakat Indonesia yang identik dengan pedesaan agraris seperti yang dijelaskan di atas akan menjadi faktor pendukung yang penting dalam pengembangan wisata kebugaran. Potensi-potensi tersebut harus dikumpulkan dan diidentifikasi secara maksimal oleh masyarakat lokal. Stimulus yang tepat harus berasal dalam diri masyarakat tersebut
Bagaimanapun juga, pemberdayaan masyarakat perlu mempertimbangkan dengan saksama mengenai tantangan dan hambatan yang menyertai proses pemberdayaan tersebut. Saat ini, upaya pengoptimalan pariwisata di Indonesia khususnya bagi wisatawan mancanegara seperti yang telah disebutkan di atas tampaknya mengalami hambatan di masa pandemi COVID-19 seperti saat ini. Bahkan, dikatakan bahwa sektor pariwisata menjadi sektor yang terdampak paling parah selama pandemi COVID-19 yang dimulai sejak 2020 lalu. Katadata (2020) menyebutkan setidaknya 10.946 usaha pariwisata telah terdampak dan 30.421 tenaga kerja di bidang pariwisata telah kehilangan pekerjaannya. Selain itu, data BPS dalam siaran pers Badan Perlindungan Konsumen Nasional mencatat tingkat hunian hotel berbintang pada Mei 2020 hanya sebesar $14,45 \%$ di mana jumlah tersebut jauh lebih kecil jika dibandingkan dengan tahun sebelumnya yang mencapai $43,53 \%$.

Perhimpunan Hotel dan Restoran Indonesia yang menyebutkan bahwa penurunan okupansi hotel berbintang dikarenakan penerapan berbagai kebijakan pembatasan salah satunya adalah PSBB selama pandemi COVID-19 di Indonesia yang berimplikasi pada berhenti beroperasinya 2.000 hotel dan 8.000 restoran. Hal tersebut juga terkait dengan pembatasan wisatawan mancanegara untuk datang ke Indonesia. Pembatasan tersebut berupa pemeriksaan dalam rangka pengendalian penyebaran COVID-19 yang terus dilakukan kepada warga negara asing yang datang ke Indonesia. Seperti yang tertulis dalam Peraturan Menteri Hukum dan Hak Asasi Manusia RI Nomor 11 Tahun 2020 tentang Pelarangan Sementara Orang Asing Masuk Wilayah Republik Indonesia yang berlaku sejak tanggal 2 April 2020 pukul 00.00 WIB hingga batas waktu yang belum ditentukan. Peraturan tersebut juga memuat larangan bagi warga negara asing untuk masuk atau transit di Indonesia dengan pengecualian yang diberikan kepada beberapa pihak yang disebutkan pula dalam peraturan. Pembatasan tersebut memberikan dampak langsung terhadap penurunan wisatawan mancanegara (wisman). Katadata (2021) mencatat kunjungan wisatawan mancanegara turun hingga $75 \%$. Jika pada tahun 2019 jumlah wisman mencapai lebih dari 16 juta dengan jumlah devisa US\$16,9 milliar, pada tahun 2020 
jumlah wisatawan tersebut turun ke angka 4,08 juta disertai dengan penurunan jumlah devisa menjadi US\$3,54 miliar.

Tidak memungkinkannya pengoptimalan pariwisata yang menyasar wisatawan mancanegara untuk datang seperti yang ditargetkan pemerintah Indonesia melalui Kementerian Pariwisata dan Ekonomi Kreatif membuat pemerintah harus memutar otak untuk dapat terus mengoptimalkan pariwisata Indonesia dengan aspek lain. Mengingat sektor pariwisata memiliki andil yang signifikan dalam devisa negara. Seperti dalam Laporan Akhir Kementerian Pariwisata dan Ekonomi Kreatif (2018) yang mencatat kontribusi sektor pariwisata terhadap PDB (\% pertumbuhan) pada tahun 2018 sebesar 5,4\%. Banyaknya andil pariwisata pada perekonomian negara memaksa pihak-pihak terkait untuk segera memulihkan kehidupan pariwisata di Indonesia. Ditambah lagi Menteri Pariwisata dan Ekonomi Kreatif RI, Sandiaga Uno saat ini telah menargetkan bahwa dalam jangka waktu 5-10 tahun ke depan, pariwisata Indonesia diharapkan mampu menyumbang PDB sebesar 10-12\% dari sebelumnya yang hanya sekitar $4,3 \%$.

COVID-19 yang membawa dampak signifikan terhadap dunia pariwisata memaksa setiap negara untuk mengubah haluan pariwisata mereka untuk dapat bertahan. Seperti contohnya China yang memilih untuk mengubah kurikulum pariwisata, sedangkan Kepulauan Pasifik memutuskan untuk mengandalkan wisatawan dan pelajar domestik (Wassler \& Fan, 2021). Melihat apa yang telah dilakukan negara lain, untuk tetap dapat mencapai target pariwisata, Indonesia dapat berpindah fokus yang semula pada wisatawan mancanegara dapat bergeser pada pengoptimalan pariwisata dengan target wisatawan domestik. Bergesernya target pariwisata yang lebih memfokuskan wisatawan domestik bukanlah hal yang mengejutkan.

Mengingat sebenarnya fokus tersebut telah tertuang dalam rencana strategis Kementerian Pariwisata dan Ekonomi Kreatif RI 20202024 yang mengubah orientasi wisatawan mancanegara (wisman) menjadi wisatawan nusantara (wisnus). Dalam keadaan seperti saat ini, yaitu selama pandemi COVID-19 masih berlangsung, sebenarnya wisatawan domestik menjadi peluang yang menjanjikan. Terbatasnya transportasi umum yang dapat digunakan untuk berwisata yang kemudian memunculkan tren penggunaan transportasi darat milik pribadi menjadi peluang tersendiri. Terlebih belum memungkinkannya masyarakat untuk dapat berwisata ke luar negeri menjadikan wisata dalam negeri menjadi pilihan. Keadaan tersebut setidaknya selama masa tanggap darurat 2020 dan masa recovery pada tahun 2021-2022 sesuai dengan kondisi global, juga sampa dengan pulihnya penerbangan internasional seiring dengan penanganan COVID-19 yang diharapkan semakin hari dapat semakin baik.

Tren baru yang dimunculkan selama pandemi COVID-19 dapat menjadi pertimbangan dalam penentuan target pengoptimalan pariwisata. Studi tentang pergeseran tren pariwisata yang dilakukan oleh Wen et al (2020) menunjukkan bahwa pandemi COVID-19 telah mengubah tren pariwisata masyarakat salah satunya adalah dengan meningkatnya pariwisata kesehatan atau kebugaran. Dalam konteks Indonesia, pergeseran tersebut selaras dengan pola new normal yang mulai diterapkan, yang mana memunculkan kehidupan dengan pola hidup sehat oleh masyarakat Indonesia. Tren menjaga kesehatan pun saat ini mulai menjadi perhatian masyarakat. Hal tersebut terkait dengan kekhawatiran masyarakat akan menurunnya imun yang nantinya akan berakibat pada mudahnya seseorang terinfeksi COVID-19.

Berbagai cara dilakukan untuk menjaga kesehatan, salah satunya seperti yang disebutkan oleh Breiner et al (2021) bahwa saat ini terjadi pergeseran kebiasaan aktivitas olahraga masyarakat menjadi lebih banyak dilakukan di rumah dengan bukti peningkatan pembelian alat olahraga pribadi. Kemudian, sebagai implikasi dari tren tersebut, back to nature saat ini menjadi isu yang semakin gencar dibicarakan masyarakat. Walaupun tren back to nature sendiri sebenarnya telah mulai muncul dari beberapa tahun terakhir, seperti yang dipaparkan oleh Yulina (2017). Tren back to nature kemudian membuat masyarakat lebih mengandalkan obat atau makanan dari bahan-bahan yang berasal dari alam untuk menjaga kesehatan mereka. Hal tersebut selaras dengan yang diungkapkan oleh Kementerian Koordinator Bidang Perekonomian (2020) bahwa beberapa daerah mengalami peningkatan yang signifikan pada penjualan obat tradisional, salah satunya Jawa Tengah dengan peningkatan penjualan sebesar $300-400 \%$. 
Theofillius Baratova Axellino Kristanto, Ayu Aishya Putri - Pengembangan Masyarakat Berbasis Aset sebagai Upaya Pemberdayaan Masyarakat melalui Sektor Wisata Kebugaran di Indonesia

Upaya pengembangan wisata kebugaran di Indonesia sangat penting untuk memahami masyarakat lokal sebagai sumber daya utama dalam proses pembangunannya. Maka dari itu serangkaian proses pemberdayaan masyarakat juga diperlukan untuk mengimbangi potensipotensi yang tersedia guna menciptakan wisata kebugaran di Indonesia. Kemudian ABCD dianggap sebagai upaya yang tepat dalam pelaksanaannya. Bukan tanpa alasan, pendekatan pemberdayaan masyarakat yang dikembangkan oleh McKnight ini berporos pada potensi dan kekuatan yang dimiliki oleh masyarakat lokal yang kemudian dari kekuatan tersebut dapat menjadi sumber daya bagi pemberdayaan masyarakat. Hal ini cukup berbeda dengan pendekatan pemberdayaan lain yang menitikberatkan pada permasalahan yang harus diatasi, $\mathrm{ABCD}$ melihat potensi yang melekat dalam masyarakat sebagai suatu titik keberangkatan bagi pemberdayaan masyarakat tersebut.

Kawasan wisata perkebunan teh Wonosari dan juga perkebunan teh Kemuning telah menjadi salah satu bentuk dari pengembangan masyarakat berbasis ABCD ini. Masyarakat mampu bergerak dari dalam ke luar melalui komunitas yang terbentuk dari spesialisasi masing-masing individu yang ada. Kemudian daripada itu intervensi-intervensi yang terjadi juga terbentuk dengan cukup baik antara pihak pemberi modal dan juga masyarakat setempat. Sehingga wisata kebugaran yang ada dapat terbentuk dengan cukup baik di kawasan wisata ini. Melalui ABCD ini tentunya dapat menjadi bentuk yang baik bagi kawasan wisata lainnya dalam mengambil model serupa untuk proses pemberdayaan masyarakat yang ada.

Maka dari itu, sinergitas antara banyak sektor dalam masyarakat, termasuk individu, komunitas, hingga potensi alamiah yang melekat pada masyarakat akan sangat membantu proses ABCD berlangsung di dalam masyarakat. Dalam konteks Indonesia, wisata kebugaran dapat dikatakan selalu ada sejauh mata memandang. Artinya kekayaan potensi wilayah-wilayah di Indonesia sangat mungkin untuk dikembangkan menjadi wisata kebugaran itu sendiri. Kemudian wisata kebugaran dengan pendekatan ABCD dinilai sebagai upaya yang tepat untuk mengembangkan sektor pariwisata ini. Pada dasarnya disebabkan oleh potensi luar biasa yang ditawarkan oleh keadaan alam hingga kekayaan struktur sosial budaya Indonesia.
Dengan memahami potensi-potensi tersebut, maka pendekatan ABCD yang bertolak dari kekuatan di dalam masyarakat tersebut sangat dapat direalisasikan secara efektif di Indonesia.

\section{Kesimpulan}

Berdasarkan pada proses pengembangan masyarakat yang terdapat di daerah perkebunan teh Kemuning dan juga Wonosari telah menunjukkan betapa pentingnya potensi internal dari kelompok yang ada sebagai sumber daya utama pembangunan. Wisata kebugaran di Indonesia dapat menerapkan skema yang sama guna mendongkrak kembali perekonomian negara yang sempat terhenti akibat pandemi COVID-19 yang ada. Maka dari itu dengan mengoptimalkan sinergitas antara masyarakat, potensi, dan juga pihak-pihak pendukung seperti pemerintah dan juga pihak swasta akan menjadi kolaborasi yang optimal dalam pengembangan wisata kebugaran di Indonesia. Konsep ABCD dengan melihat perkembangan yang terjadi dalam dua contoh perkebunan teh di atas adalah gambaran yang sesuai untuk meningkatkan pengembangan wisata kebugaran di Indonesia dalam skala yang lebih besar.

\section{Referensi}

Agustina, N. K. W., \& Yudhistira, P. G. A. (2021). Analysis of Tirta Empul Development Strategy as Wellness Tourist Attraction in New Normal Era. Journal of Business on Hospitality and Tourism, 7(1), pp. 114-126. doi: http://dx.doi.org/10.22334/jbhost. v7i1.279.

Andreu, M. G. N. L., Font-Barnet, A., \& Roca, M. E. (2021). Wellness Tourism-New Challenges and Opportunities for Tourism in Salou. Sustainability, 13(15) pp. 1-13. doi: https://doi.org/10.3390/su13158246.

Badan Perlindungan Konsumen Nasional. (2020). BPKN Minta Kemenpar Terbitkan Panduan Normal Baru Pariwisata. https:// www.bpkn.go.id/posts/show/id/1879 accessed on 12 July 2021.

Badan Pusat Statistik. (2021). Jumlah kunjungan wisman ke Indonesia bulan Desember 2020 mencapai 164,09 ribu kunjungan. https://www.bps.go.id/ pressrelease/2021/02/01/1796/jumlahkunjungan-wisman-ke-indonesia-bulandesember-2020-mencapai-164-09-ribukunjungan-.html accesed on 15 July 2021. 
Baskara, Medha, dan Sitawati. (2005). Konsep Pengembangan Wisata Agro Kebun Teh Wonosari: Usaha Diversifikasi dalam Meningkatkan Nilai Tambah Pengelolaan Perkebunan Teh. Prosiding Seminar Nasional Perhimpunan Agronomi Indonesia (PERAGI).

Breiner, C. E., Miller, M. L., \& Hormes, J. M. (2021). Changes in eating and exercise behaviors during the COVID-19 pandemic in a community sample: A retrospective report. Eating Behaviors, 42, pp. 1-6. doi: https://doi.org/10.1016/j. eatbeh.2021.101539.

Chen, K. H., Chang, F. H., \& Wu, C. (2013). Investigating the wellness tourism factors in hot spring hotel customer service. InternationalJournal ofContemporary Hospitality Management. doi: https://doi. org/10.1108/IJCHM-06-2012-0086.

Cohen, J. M., \& Uphoff, N. T. (1980). Participation's place in rural development: seeking clarity through specificity. World development, 8(3), pp. 213-235. doi: https:// doi.org/10.1016/0305-750X(80)90011-X.

Cronin, P., Ryan, F., \& Coughlan, M. (2008). Undertaking a literature review: a stepby-step approach. British journal of nursing, 17(1), pp. 38-43. doi: https://doi. org/10.12968/bjon.2008.17.1.28059.

De la Barre, S. (2005). Not" Ecotourism"?: Wilderness Tourism in Canada's Yukon Territory. Journal of Ecotourism, 4(2), pp. 92-107. doi: https://doi. org/10.1080/14724040409480342.

Foot, J. \& Hopkins, T. (2009). A glass half-full: o wan asset approach can improve community health and well-being. Improvement and Development Agency (IdeA).

Katadata.co.id. (2020, 16 July). Rumitnya Menyambung Napas Industri Pariwisata Saat Pandemi. https:// katadata.co.id/muhammadridhoi/ indepth/5f115247a92b6/rumitnyamenyambung-napas-industri-pariwisatasaat-pandemi accessed on 12 July 2021.

Katadata.co.id. (2021, Maret 22). Menparekraf: Kontribusi Pariwisata Ditargetkan 12 Persen dari PDB. https://katadata.co.id/ doddyrosadi/berita/6058264566a4b/ menparekraf-kontribusi-pariwisataditargetkan-12-persen-daripdb\#: : text=Pada $\% 202019 \% 2$ C\% 20 devisa $\% 20$ sektor $\% 20$ pariwisata, $96 \% 20$ juta\%20orang\%20pada $\% 202019$ accessed on 12 July 2021

Kementerian Koordinator Bidang Perekonomian Indonesia. (2020). Konsumsi Jamu Meningkat, Pemerintah Berdayakan UMKM dengan Pendekatan Klaster Obat Tradisional. https://www.ekon.go.id/ publikasi/detail/493/konsumsi-jamumeningkat-pemerintah-berdayakanumkm-dengan-pendekatan-klaster-obattradisional accessed on 12 July 2021

Kementerian Pariwisata dan Ekonomi Kreatif. (2020). Rencana Strategis 2020-2014. https://www.kemenparekraf.go.id/ asset_admin/assets/uploads/media/ pdf/media_1598887965_Rencana_ strategis_2020-2024.pdf accessed on 14 July 2021.

Kementerian Pariwisata dan Ekonomi Kreatif. (2018). Kajian Dampak Sektor Pariwisata Terhadap Perekonomian Indonesia. https://www.kemenparekraf.go.id/ asset_admin/assets/uploads/media/pdf/ media_1554437393_Laporan_Akhir.pdf accessed on 12 July 2021.

Kementerian Pariwisata dan Ekonomi Kreatif. (2019). Journey For Healthy-Life: Skenario Perjalanan Wellness Tourism di Joglosemar, Bali dan Jakarta. Jakarta: Deputi Bidang Pengembangan Industri dan Kelembagaan Kementerian Pariwisata dan Ekonomi Kreatif

Kurniawan, L.L. (2018). Promoting Indonesia as a Wellness Tourism Destination. KnE Social Sciences, 3(10). doi: https://doi. org/10.18502/kss.v3i10.3378.

McKnight, J. (2017). Asset-based community development: the essentials. Chicago: AssetBased Community Development Institute.

Meera, S., \& Vinodan, A. (2019). Attitude towards alternative medicinal practices in wellness tourism market. Journal of Hospitality and Tourism Insights. 2(3), pp. 278-295. doi: https://doi.org/10.1108/JHTI-06-2018-0037.

Meikassandra, P., Prabawa, I. W. S. W., \& Mertha, I. W. (2020). Wellness Tourism In Ubud." A Qualitative Approach To Study The Aspects Of Wellness Tourism Development. Journal of Business on Hospitality and Tourism, 6(1), pp. 79-93. doi: http://dx.doi.org/10.22334/ jbhost.v6i1.191.

Motevalli-Taher, F., \& Paydar, M. M. (2021). Supply chain design to tackle coronavirus pandemic 
Theofillius Baratova Axellino Kristanto, Ayu Aishya Putri - Pengembangan Masyarakat Berbasis Aset sebagai Upaya Pemberdayaan Masyarakat melalui Sektor Wisata Kebugaran di Indonesia

crisis by tourism management. Applied Soft Computing. 104, 107217. doi: https://doi. org/10.1016/j.asoc.2021.107217.

Mueller, H., \& Kaufmann, E. L. (2001). Wellness Tourism: Market analysis of a special health tourism segment and implications for the hotel industry. Journal of vacation marketing, 7(1), pp. 5-17. doi: https://doi. org/10.1177/135676670100700101.

Nasdian, Fredian Tonny. (2014). Pengembangan Masyarakat. Jakarta: Yayasan Pustaka Obor Indonesia.

Paul, S. (1987). Community Participation in Development Projects - The World Bank Experience. Washington DC: The World Bank.

Pusat Studi Biofarmaka Tropika. (2020). Sebanyak 80 Persen Tanaman Obat Dunia Ada di Indonesia. http://fmipa.ipb.ac.id/ sebanyak-80-persen-tanaman-obat-duniaada-di-indonesia/ accessed on 15 July 2021.

Rahmat, A. (2010). Perkebunan Teh Kemuning dan Dampaknya Terhadap Masyarakat Lokal Tahun 1945-1965. Skripsi. Surakarta: Universitas Negeri Sebelas Maret.

Ross, K. (2001). Health Pariwisata: An overview. HSMAI Marketing Review, December.

Sigala, M. (2018). New technologies in tourism: From multi-disciplinary to anti-disciplinary advances and trajectories. Tourism management perspectives, 25 , pp. 151155. doi: https://doi.org/10.1016/j. tmp.2017.12.003

Snyder, H. (2019). Literature review as a research methodology: An overview and guidelines. Journal of business research, 104, pp. 333-339. doi: https://doi.org/10.1016/j. jbusres.2019.07.039.

Steiner, C. J., \& Reisinger, Y. (2006). Ringing the fourfold: A philosophical framework for thinking about Wellness Tourism. Tourism recreation research, 31(1), pp. 5-14. doi: https://doi.org/10.1080/02508281.2006. 11081242.

Steiner, C. J., \& Reisinger, Y. (2006). Ringing the fourfold: A philosophical framework for thinking about Wellness Tourism. Tourism recreation research, 31(1), pp. 5-14. doi: https://doi.org/10.1080/02508281.2006. 11081242.

Utama, I., \& Nyandra, M. (2021). Health and Wellness Tourism Industry: Types and Development Potentials in Bali, Indonesia. International Journal of Social Science and Education Research Studies, 1(1), pp. 08-12. http://ijssers.org/index.php/ijssers/article/ view $/ 4$.

Wassler, P., \& Fan, D. X. (2021). A tale of four futures: Tourism academia and COVID-19. Tourism Management Perspectives, 38, 100818. doi: 10.1016/j.tmp.2021.100818.

Wen, J., Kozak, M., Yang, S., \& Liu, F. (2020). COVID-19: Potential effects on Chinese citizens' lifestyle and travel. Tourism Review. doi: https://doi.org/10.1108/TR-03-20200110.

Yulina, I. K. (2017). Back to Nature: Kemajuan atau Kemunduran. Mangifera Edu, 2(1), 2031. doi: doi.org/10.31943/mangiferaedu. v2i1.15 